\title{
The Meaning and Implication of ICCPR Ratification to Religious Freedom in Indonesia
}

\author{
Saru Arifin \\ Universitas Negeri Semarang \\ Kampus Sekaran, Gedung K Gunungpati \\ Semarang-Jawa Tengah \\ saruarifin@mail.unnes.ac.id
}

\begin{abstract}
Indonesia has officially ratified the ICCPR in 2005. This Covenant is one of the basic human rights law instruments in the United Nations. This paper is aimed to review the implication of the Covenant to human rights law system in Indonesia in general, and particularly for the religious freedom. Unfortunately, the violation on behalf of the religions has enormously increased since 2005 until present. The result of the research reveals that human right laws related to freedom of religion in Indonesia, such as the President Decree Number 1 year 1965 on the Prevention of Blasphemy substantially needs to be harmonized with the ICCPR. This is because the national law harmonization is required as a consequence of the Covenant either substantially or formally. In this context, the Covenant transformation to national law was stagnant. The ratification of the Covenant only finished as an official action; in fact, it needs the following actions such as harmonization and socialization to the state apparatuses. Hence, the differentiation interpretation of the religious freedom has become among scholars and state apparatuses, and in particular case it impacted to the violation of any religion's followers.
\end{abstract}

Keywords- The Freedom of Religion; Human Rights Law; ICCPR; Ratification;

\section{INTRODUCTION}

Freedom of religion is a fundamental right that is universally recognized by the international community.[1] Religion is essentially a collection of beliefs that govern certain provisions for life. It is a very personal matter. (Dickson, 1995) The law can not force people to believe in a certain set of religious beliefs. According to Koentjaraningrat (Koentjaraningrat, 1985), religion is a system that consists of four components. First, emotions, beliefs that cause people to be religious. Second, a belief system that contains all conviction, and the shadow of man on God's attributes, supernatural beings, as well as all the values, norms, and teachings of the religion in question. Third, the system of rites and ceremonies which are man's efforts to seek a relationship with God, gods or spirits that inhabit the supernatural. Fourth, race or national unity to embrace belief systems, and conducting the system of rites and ceremonies.
Four components are connected with one another, so that they become an integrated system unanimously. Religious purposes should be associated with those components. In other words, the interests of religion concern with the interests of religious emotions, belief systems, ritual system, and the people who constitute one unit. Religious interests can be compressed into interests related to belief systems, rites system, and the people, while the religious emotion underlies all of it (Supanto, 2007).

In the context of Indonesia, religion plays an important role in people's lives. This is stated in the Indonesian national ideology, Pancasila, which is expressly stated in the first principle: "Belief in God Almighty." In this context, a number of religions in Indonesia collectively influence politics, economics and culture (Wikipedia, ). Likewise, in the life of the world community, religion in its various forms also affects the privacy of not only followers, but also on public policy (Trigg, 2007).

Article 29 of UUD 1945 stated that "each citizen is given the freedom to choose and practice the faith" and "guarantee everything will be the freedom to worship, according to the religion or belief." Given the importance of the role of religion in the life of the nation, the government is concerned to maintain the harmony in the relationship between religion and religion internally, through a number of legislative policy. One of them is with the issuance of Presidential Decree No.1 Year 1965 About Abuse Prevention and/or blasphemy. The provision of Article 1 of Presidential Decree No. 1 Year 1965 stated, that religions are embraced by the population in Indonesia are Islam, Christianity, Catholicism, Hinduism, Buddhism and Confucianism [2].

In accordance with the provision of the Constitution of the Republic of Indonesia Year 1945, which mandates the promotion and protection of human rights in the society, nation and state, and the nation's commitment to Indonesia as part of the international community to promote and protect human rights, Indonesia demonstrates its commitment to ratify the main international instruments on human rights. They are the International Covenant On Economic Rights, Social, and Cultural Rights and the International Covenant on Civil and Political Rights. 
Law No. 11 Year 2005 on Ratification of the International Covenant on Economic, Social and Cultural Rights, and Law No. 12 Year 2005 on the Ratification of the International Covenant on Civil and Political Rights, give hope that there is a justice and legal certainty for people who have been craved the enforcement of human rights [3].

With the two laws mentioned above, Indonesia has completed the acceptance of the International Law of Human Rights. Earlier, Indonesia's acceptance of International Law of Human Rights or in the international world known as International Bills of Human Rights made to the Universal Declaration of Human Rights. Although the declaration is non-juridical instruments, all members of the United Nations, including Indonesia, must acknowledge and accept the main ideas contained in the Declaration (Al-Amin, 2007).

Thus, in accordance with the Law No. 39 Year 1999 on Human Rights, Law No. 11 Year 2005 on the Ratification of the International Covenant on Economic, Social and Cultural Rights, and the Law No. 12 Year 2005 on Ratification of the International Covenant on Civil and politics, there should be no reason for Indonesia to not uphold human rights community. Therefore, Indonesia already has regulations or court to resolve violations. Freedom of religion as an essential part in human rights [4] has been explicitly stated in the international covenant as a right that must be respected by anyone, including the government. This statement is contained in the provisions of Article 18 of the ICCPR which states:

1. Everyone has the right to freedom of thought, conscience and religion. This right includes freedom to embrace religion or belief of his choice alone, and freedom either alone or jointly with others, in public or private, to manifest his religion or belief in worship, compliance, practice and teaching.

2. No one can be forced, so impaired their freedom to embrace religion or belief or set preferences.

3. Freedom to manifest one's religion or belief sets can only be restricted by law and are necessary to protect public safety, order, health or morals or the rights and freedoms of others.

4. States parties to the present Covenant undertakes to respect the liberty of parents and, when applicable, legal guardians to ensure the religious and moral education of their children in accordance with their own convictions.

In a practical context, religion is generally manifested through various forms of worship and acts of showing obedience. This is Often done together with others who have the same beliefs, so that freedom of religion often involves rights of groups.

International covenants mentioned above, allowed all to believe and even to believe nothing. As such, it covers all the major religions, any local religions, belief systems exist, and the right not to trust anything. So, the atheists and agnostics are also included. Another thing that is covered and very controversial is the right to religious conversion. [5] Because some formal religions do no recognize the autonomy of the individual to convert his religion, guarantee of rights aspect is sometimes problematic for the country. Coercion can not be made to individuals to change the religious beliefs espoused. Even the Cairo Declaration on Human Rights in Islam states, prohibited the use of force in any form to humans or to take advantage of poverty or ignorance in order to convert his belief to a religion or to atheism [6].

As a former special rapporteur, Ribiero noted a law of thought which holds that individuals should be free not only to choose the different choices of theistic beliefs and to practice freely, but also have the right to look at life from the perspective of a non-theistic, without having to suffer a particular disadvantage compared with those who believe. The Special Rapporteur was of the opinion that the same is the case with people who believe in religion/belief that should enjoy the right to practice their religion without hindrance, they are not faiths (free thinkers, agnostics, and atheists) that should also not be discriminated [7].

The inclusion of religion in the public register of the character "non-discrimination" is to indicate the acceptance of it as an attribute that can not be revoked and very personal, as well as gender, race and language (other generic indicators of discrimination). It is argued that discrimination on the basis of trust is perhaps even jus cogens. (Brownlie, 1991) Because many religions are embraced by the public in some countries, there is a cross-border element in freedom of religion, so it is worthy of international law to regulate freedom of religion. (Azcarate, 1945) But in fact, throughout history, religious conflict has colored international relations. The history of religions, especially in Indonesia, according to Umar, (Umar, 2006) is colored by the tensions that ended in bloodshed among fellow believers. In the name of religion, each group felt the most right while converting or labeling infidel one another.

In a similar context in Europe, according to Lehnhof, (Lehnhof, 2002) stance competing for legitimacy of government by religious groups, such as Christians, Jews, Muslims and other faith groups, has sparked a debate among human rights activists, so it was a bit much trigger tension in the relations among religious groups.

In this regard, in mid-September 2006, the Ministry of the United States released its latest report on religious freedom in Indonesia. Routinely, the institute publishes an annual report on religious freedom conditions in various countries in the world with reference to events related to the issue of religion over the last year (Assyaukanie, 2007).

In general, there is nothing surprising about the contents of the report. The condition of religious freedom we are concerned and there has been no significant change from previous years. Violations and discrimination against minority groups are frequent and violent acts in the name of religion, have not stopped. The report said some of the factors that drive the emergence of discrimination and violations of religious freedom in Indonesia. Of them, he said the government and the lack of desire to change this situation. In some cases, governments have instead assessed silence cases of violations of religious freedom. If there is action, the perpetrators are usually free from the law. 
Based on the above description, it appears that religious freedom has gained widespread legal guarantees in the international community through numerous human rights instruments, and in the context of Indonesia, the commitment to the promotion of human rights is also strengthened by the ratification of ICCPR and ICESCR two covenants, as well as some products of national legislation related. Regarding to this, the question can be formulated as follows: First, how important is the ratification of the ICCPR covenant in the promotion of human rights in Indonesia, particularly in the field of religion. Second, how is the implication of the ICCPR ratification on the right to freedom of religion in Indonesia.

\section{RATIFICATION OF THE ICCPR}

\section{A. Significance and Covenant Binding}

On December 16, 1966, with a resolution 2200A (XXI), UN endorsed General Assembly to enact the Covenant on Civil and Political Rights together with the Optional Protocol to the Covenant on Civil and Political Rights and the Covenant on Economic, Social and culture. International Covenant on Civil and Political Rights and its Optional Protocol to the International Covenant on Civil and Political Rights applied on March 23, 1976.

The International Covenant on Civil and Political Rights (ICCPR) is a product of the Cold War. Covenant is the result of a political compromise between the forces of violent Socialist bloc against capitalist bloc. At that time, this situation affected the legislative process of international human rights treaties that when it was being worked on the UN Human Rights Commission. The result was the separation of categories of civil rights and political rights in a category of economic, social, and cultural rights into two covenants or treaties - which was sought to be integrated into a covenant only, but the political reality requires another one. (Al-Amin, 2007) The other covenant is the International Covenant on Economic, Social and Cultural Rights (ICESCR). Both of these covenants are twins, which were born under circumstances that are not so favorable, which has brought certain implications in the enforcement of the two categories of rights.

The ICCPR is one of the documents of international law along with the ICESCR and the UDHR-that form of international human rights law (the international bill of rights). On this basis, it can be said that the ICCPR is one of the most fundamental document in the regime of international human rights law. This is very clear, in particular, relating to the protection of civil rights and politics. (Schwelb, 1972)

Besides that, in fact ICCPR as adoption where more than one hundred countries did in 1966. Up to now, the ICCPR has been ratified by almost all countries in the world. However, explicitly McGoldrick proposed a rebuttal of the views of the ICCPR which states that the document was established on the basis of an individualistic Western philosophy (McGoldrick). Moreover, the ICCPR is a further elaboration of various freedoms of civil and political rights that were previously contained in the UDHR. There is even a view that the ICCPR is a statement of human rights obligations in the Charter. (Symonides)

Universality has provided a strong foundation for the countries that are not as participants to obey. The arguments are as follow. First, some of the provisions of the ICCPR have been a part of what is called the norm in customary law. As a consequence, the norms that have become part apply binding on all states without exception. This argument was put forward by, among others, Thedor Meron (Meron, 1989) and American courts in the case of Filartiga. [8]

Second, the argument is put forward by, among others, who see Egon Schwelb ICCPR is binding on all states without questioning whether the country has ratified or not. The binding strength is solely due to the ICCPR is seen as a further elaboration of the human rights obligations that were previously stated in the UN Charter. This view was rejected by McGoldrick [9] for acceptance at the time. It was just less than half of the UN member states. However, McGoldrick admitted that historically there is a relationship between the two. So that argument is based only on the number of admissions. Therefore, if the argument is applied to the current context in which the recognition of the ICCPR is common, then the argument is no longer valid.

Third, the argument believes that the ICCPR is a reflection of general principles of law recognized by civilized nations (Hevener, 1978). As mentioned above in fact all the views can not be said to be wrong because in the current context ICCPR has become a fundamental part of the legal regime of human rights, both at international and national levels, the ICCPR has a mechanism that occupies a very important location [10]. Even in those countries that embrace monism though, the ICCPR is crowned as the supreme law.

However, the ICCPR is a document that has a very important position in the universal system of human rights protection. The nature that has binding force against the country participants has made not only limited to mere expressions of universal morality. But more than that, it has become a means of coercion to the parties, so it's been said to be proper if the ICCPR 'last refuge (the last resort)' for seekers who have been denied justice at the national level.

\section{B. Scope of Regulation}

Basically, ICCPR contains provisions regarding restrictions on the use of authority by the state's repressive apparatus, especially the state's repressive apparatus of the States Parties to the ICCPR. Hence the rights accumulated in it also often referred to as negative rights. [11] This means that the rights and freedoms guaranteed therein will be satisfied if the state's role limited or seen minus. But when the state has an interventionist role, it is inevitable the rights and freedoms set forth therein would be infringed by the state. This is what distinguishes it from the model legislation of the International Covenant on Economic, Social and Cultural Rights (ICESCR) is actually demanding role of the state maximum. It actually violated the rights guaranteed therein if the state does not play an active or a minus indicates a role, and ICESCR is often referred to as positive rights. 


\section{Ratification Context for Indonesia}

With the Law No. 39 Year 1999 on Human Rights, Law No. 11 Year 2005 on the Ratification of the International Covenant on Economic, Social and Cultural Rights, and the Law No. 12 Year 2005 on Ratification of the International Covenant on Civil and Political Rights, there should be no reason for Indonesia not to enforce the human rights community. This is because Indonesia has already had regulations or court to resolve the violations.

Hikmahanto Juwana stated that there are some challenges that the government of Indonesia after the ratification of the ICCPR. First, the government should do a post-ratification of the ICCPR to transform and translate norms in the ICCPR into domestic law. This transformation can be in the form of amending or proposing new legislation as mandated by the ICCPR. Governments have to comb the various laws and regulations that are not in conformity with the ICCPR.

Second, the law enforcement officials have to understand the various laws that have been amended or made anew as a consequence of the ratification of the ICCPR. Without a good understanding of the law enforcement agencies, it would be hard to imagine the ICCPR has meaning in society.

Third, the Government has an obligation to ensure that the provisions of the ICCPR which was transformed into the legislation could apply uniformly throughout Indonesia.

Fourth, the government should provide the supporting infrastructure for the implementation of legislation transforming the ICCPR. Indonesia often encountered in law enforcement should work with minimal support infrastructure law. Prison in very poor conditions, laws and regulations are not available for judges and more.

Fifth, the government is obliged to change the culture of the Indonesian people and government officials who are less aware of human rights, including in the field of civil and political, to be very aware. Sometimes the legislation failed to apply because it is not supported by the legal culture of society.

\section{IMPLICATIONS THE COVENANT RATIFICATION}

In the perspective of human rights, the government intervention through the MUI and Coordination Agency Adherents Religious Faith and Faith (Bakorpakem), which issued the prohibition and dissolution of the Ahmadiyah, was not in harmony with the provisions of the ICCPR Covenant, especially Article 18 because the expression in any form of religious belief was protected by these covenants. In this context, Indonesia has ratified the ICCPR Covenant is seen as not consistent in its application. Though Indonesia did not make reservations or declarations on ICCPR article related to religious freedom. In addition, freedom of religion has been a part of jus cogen. Even if Indonesia ratified, it would not reduce any obligations. As a consequence, Indonesia is required to apply in accordance with the interpretation given by the Human Rights Committee as the only organ that has full authority over the implementation of the ICCPR.

In the covenant provisions, affirmed the obligations imposed on the state-participants contained in Part II ICCPR Article 2-5. This provision can not be used as the object of reservation. The authority to interpret the obligations assumed by the state-owned participants by the Human Rights Committee as the treaty-based organ of his ICCPR. The authority is not independent of Article 40 (2) which enable the Committee to carry out an assessment of the reports of the countries-participants about the implementation of the ICCPR in their respective countries.

As a consequence, the Committee adopted a General Comment, where in it is good advice or interpretation of the Committee on the provisions of the ICCPR, to determine the obligations assumed by the state-participants, and should be noted further on General Comments provided by the Committee in addition to the articles of the ICCPR which regulates it. The comment associated with it is No. 31, entitled Nature of General Legal Obligation imposed on States Parties of the Covenant. No comments supersede Comment 3 as the form has the latest developments.

General Comment states if the obligation contained in Article 2 Brazilians are erga omnes obligations. As a consequence, each participating country has a duty to watch over the protection of the rights in other participating countries. Therefore, when a failure of a party to show the other participating countries are not to be considered as a hostile act, it must be understood in relation to the fulfillment of its obligations towards the international community as a whole.

Obligations imposed by the Covenant shall be binding on the participating countries as a whole. That is, all branches of government and other government officials without exception are bound by this obligation as well. This view cannot be separated from the provision contained in Article 27 of the Vienna Convention on Law Treaties (VCLT) where the participants are not allowed to make the provisions of its internal law as justification for its failure to fulfill its international obligations.

In this chapter there is also the term 'individual' without reference to nationality. Covenant includes all individuals who are in a jurisdiction and that the subject of the participating countries. Sense includes all those individuals who are in the area that became part of the jurisdiction without considering the status. (Lillich, 1984)

Of this provision, then rationae personae and loci are broadly covers all individuals in its territory and which are outside though. This applies in relation to, for example, the citizens who are performing their duties as peacekeepers abroad. Individuals are the only objects for the protection of the Covenant with the exception of Article 1. However, in relation to the communication under the First Additional Protocol, the comments provide an exception to give possible for a group of individuals to submit communications.

The obligation to respect and guarantee contained in Article 2 (1). The obligation to respect had an understanding 
of the obligations is negative. That is, the participating countries are not required to perform various actions. For example, the participants are required to refrain from restrictions of freedom of expression. While the obligation to ensure meaningful as a positive obligation. That is, the participants are required to be pro-actively associated with the realization of the rights. For example, with respect to the realization of the right of every citizen to participate in a variety of public life, of course, this requires a party to hold a mechanism that can enable these rights are realized. Both of these obligations must be performed by the participating countries in relation to good faith as stated in Article 26 VCLT.

The shape of the obligations imposed on the stateparticipants in relation to the realization of the rights can be done in various forms. For example, in the form of legislation, administrative, educational or other actions that can support the objective of the Covenant implementation. In addition, the Committee also believes that an increasing knowledge of the general public was not as important as increasing the knowledge of the authorities in relation to the Covenant.

The obligation in Article 2 (1) shall be binding on the states-participants and does not have a direct horizontal effect. Covenant should not be viewed as substitutes for the products of local laws. However, when the participants must provide protection for individuals from violations committed by its agents and other parties. Failure is considered to occur when the participants leave or fail to take appropriate measures related to the prevention, punishment, investigate or repair damages caused by persons or an institution.

Article 2 (2) requires the states to take measures necessary for the implementation at the local level. The state-participants who do not have the legal instrument that clearly protects the rights required to make changes. When there is a conflict between local laws and the Covenant then the first must be adjusted to the standards provided by the Committee.

In addition, although the participating countries are not required to make the Covenant be directly used in the local court, but the Committee encourages the State Party not to embrace monism that incorporating the Covenant as part of the local law. In addition, Article 2 (2) requires the states to implement it immediately. This obligation should not be overlooked just because of social reasons, politic, economy and culture of the country concerned.

\section{CONCLUSION}

Indonesia ratified the action taken against the covenant ICCPR is a concrete manifestation of the Indonesian nation to participate in the promotion and enforcement of human rights, especially in the field of freedom of religion. This has been followed by Indonesia in the realm of regulation and human rights institutions. However, the transformation process still requires a lot of adjustment, both in the legal system, culture, and credible institutions in the promotion of human rights, especially in the field of freedom of religion. In addition, the implications of the Covenant ICCPR ratification by Indonesia, especially in the field of freedom of religion requires the harmonization of regulatory level, and at the same time transforming the values of human rights contained in the Covenant as a whole, so that the handling of religious freedom can run in accordance with the demands of the covenant.

\section{REFERENCES}

[1] It is indicated by the inclusion of the right to freedom of religion in the UDHR, and the covenants, such as the ICCPR, ICESCR and others.

[2] Limitation of the "official religion" and "unofficial", announced by the government may also result in violation of human rights, particularly minority communities where their religious practices and forms are not recognized by the State. The fact is in violation of the provisions of the present Convention, including Article 2, Article 4, Article 18, Article, 26, and Article 27. See Gubugbudaya, 2007, Hak Minoritas di Indonesia, Sccessed on April 29, 2008 from http://gubugbudaya.wordpress.com/2007/06/08/artikel-27-iccpr-hakminoritas-di-indonesia/.

[3] Published in the State Gazette of the Republic of Indonesia Year 2005 Number 118, Supplement to State Gazette of the Republic of Indonesia Number 4557.

[4] Al-Amin, explicitly spell out the difference between the notion of human rights with civil rights. According to him, human rights are rights inherent to the human who is not born with any gift, which the religious right is a right granted by God and not by man, even by the state. While civil rights are the rights of every person due to his citizenship. Civil rights in the community or individual means an obligation for the state. Thus, civil rights are protected or guaranteed by the state, and the public is entitled to demand full rights and may sue the state if their rights denied. Human rights are more fundamental, but not necessarily protected by the state. See, Bahr Al-Amin Haq, 2007, Prospek ... Ibid.

[5] See full description of the issue in Vyver, Johan D. Van der and Witte, Jr.. John, 1996, Religious Human Rights in Global Perspective: Legal Perspectives, Martinus Nijhoff Publishers, London, and The Declaration on the Elimination of All Forms of Intolerance and of Discrimination based on Religion or Belief (EAIDRB).

[6] The 19th Conference of Foreign Ministers OIC countries, August 5, 1990

[7] A. Ribiero, Report to the Commission on Human Rights, UN Doc E/CN.4/1990/46, paragraf 113.

[8] International Legal Materials 19 (1980). p. 966.

[9] Acceptance of the ICCPR in June 2003 has reached 143 countries whereas the total number of UN member states is only 191 countries

[10] At this time the Committee faced problems related to the influx of first optional protocol use by individuals. See Henry J. Steiner, 'Individual Claims in a World of Massive Violations: What Role for the Human Rights Committee?,' in Philip Alston and James Crawford (eds.), 2000, The Future of UN Human Rights Treaty Monitoring, Cambridge University Press, Cambridge. See also Fact and Figures on 2005 Communications.

[11] Simply put, there are two classifications of the rights contained in the ICCPR negative it. The first classification is the rights of the kind of non-derogable, i.e the rights that are absolute must not be reduced compliance by States Parties. Although in a pinch though. The rights that are included in this type are: (i) the right to life (rights to life), (ii) the right to freedom from torture (rights to be free from torture), (iii) the right to freedom from slavery (rights to be free from slavery), (iv) the right to be free from arrest for failing to fulfill the agreement (debt), (v) the right to be free from retroactive punishment (vi) rights as a subject of law, and (vii) the right to freedom of thought, the assurance and religion. States Parties which violate the rights of this type, will often criticized as a country that has committed serious abuses of human rights (gross violation of human rights). The second group is the kind of rightderogable rights, which rights may be reduced or limited compliance by States Parties. Rights and freedoms that belong to this type are: (i) the right to freedom of peaceful assembly, (ii) the right to freedom of 
association, including the form and join trade unions, and (iii) the right to freedom of expression or of expression, including freedom of seek, receive and impart information and ideas of all kinds regardless of the limit (either through oral or written). Responsibility for the protection and fulfillment of all rights and freedoms promised in the Covenant is on the shoulders of the state, particularly the State Party ICCPR. Look in Bahr Al-Amin Haq, 2007, Human Rights and the ICCPR .... Op.Cit.

[12] Al-Amin, Bahrul Haq, 2007, Prospek Demokrasi dan Hak-hak Sipil Keagamaan di Indonesia, diakses pada tanggal 11 April 2008 dari http://www.bahrulhaq.multiply.com/journal/item/25.

[13] Ancok, Jamludin dan Nashori, Fuad, 1994, Psikologi Islami, Pustaka Pelajar, Yogyakarta.

[14] Antara, Aqil Siroj Tanyakan Status MUI, diakses pada tanggal 18 Maret 2008 dari situs http://www.antara.co.id/arc/2007/11/30/aqil-sirojtanyakan-status-mui/

[15] Assyaukanie, Luthfi, Catatan Kebebasan Beragama Kita, diakses tanggal 3 Januari 2007 dari http://www.assyaukanie.com/articles/catatankebebasan-beragama-kita.

[16] Aziz, Hamid, 2005. Majelis Ulama Menyoal Ahmadiyah, diakses pada tanggal 9 Mei 2006 dari http://www.icmi.or.id/ind/content/view/218/60/.

[17] B. Dickson, 1995, 'The United Nations and Freedom of Religion", Jurnal International and Comparative Law Quaterly.

[18] Brownlie, Ian, 1991, Principles of International Law, Oxford University Press, Oxford, (edisi IV).

[19] Dinata, Arda, 2007, Memaknai Hakekat Kebebasan dalam Islam, diakses pada tanggal 14 April 2008 dari http://miqrajurnal.blogspot.com/2007/11/memaknai-hakekat-kebebasandalam-islam.html

[20] De Azcarate, P. 1945, League Nations and National Minorities: An Experiment, Carnegie Endowment For International Peace, Hague, New York.

[21] Gubugbudaya, 2007, Hak Minoritas di Indonesia, diakses pada tanggal $29 \quad$ April 2008 dari http:/gubugbudaya.wordpress.com/2007/06/08/artikel-27-iccpr-hakminoritas-di-indonesia/

[22] Hevener, N.K. dan Mosher, S.A. 'General Principles of Law and the U.N. Covenant on Civil and Political Rights,' dalam International Comparative Law Review 27 (1978).

[23] Hosen, Nadirsyah, 2006, Demokrasi dan Perlindungan Kaum Minoritas, diakses pada tanggal 29 April 2008 dari http://islamlib.com/id/index.php?page=article\&mode=print\&id=1043

[24] Juwana, Hikmahanto, Tantangan Indonesia Pasca Ratifikasi ICCPR, diakses pada tanggal 18 April 2008 dari http://www.kompas.com/kompas-cetak/0506/08/opini/1799437.htm.

[25] Koentjaraningrat, 1985, Kebudayaan, Mentalitas, dan Pembangunan, Gramedia, Jakarta.

[26] Lehnhof, Lance S. 2002, Freedom of Religious Association: The Right of Religious Organizations Legal Entity Status Under the Uropean Convention, Brigham Young University Law Review; ABI/INFORM Global, p. 561.

[27] Lillich, R.B. 1984, The Human Rights of Aliens in Contemporary International Law, Manchester University Press, Manchester.

[28] Mabruri, Gufron, et al., 2006, Demokrasi Selektif terhadap Penegakan HAM: Laporan Kondisi HAM Indonesia 2005, Imparsial, Jakarta.

[29] Meron, Theodor, 1989, Human Rights and Humanitarian Norms as Customary International Law, Oxford University Press, Oxford.
[30] Muzakki, Akh. Fatwa dan Kekerasan, diakses pada tanggal 19 Februari 2008

http://www.gusdur.net/indonesia/index.php?option=com_content\&task= view\&id=2768\&Itemid=1

[31] Nasrudin, Menimbang Otoritas Fatwa MUI, diakses pada tanggal 18 Maret $2008 \quad$ dari r situs http://www.nasrudincakep.blogspot.com/2007/11/menimbang-otoritasfatwa-mui.html

[32] Rahardjo, M. Dawam, Dasasila Kebebasan Beragama, diakses tanggal 16 Juni 2007, pukul 10:03:29 pm. dari http://islamlib.com/id/index.php?page=article $\& \mathrm{id}=925$.

[33] -------------, Negara, Agama dan Penegakan Hak Sipil, diakses tanggal 17 Juni 2007, pukul 08:43:14 pm. dari http://icrponline.org/wmview.php?ArtCat=2\&pos $=15$.

[34] Ribiero, A. Report to the Commission on Human Rights, dok PBB E/CN.4/1990/46, paragraf 113.

[35] Schwelb, Egon, 'The International Court of Justice and the Human Rights Clauses of the Charter,' dalam American Journal of International Law 88 (1972).

[36] Steiner, Henry J. 'Individual Claims in a World of Massive Violations: What Role for the Human Rights Committee?,' dalam Philip Alston dan James Crawford (eds.), 2000, The Future of UN Human Rights Treaty Monitoring, Cambridge University Press, Cambridge.

[37] Sukardja, Ahmad, 1995, Piagam Madinah dan Undang-Undang Dasar 1945. UI Press, Jakarta.

[38] Supanto, 2007, Delik Agama, Lembaga Pengembangan Pendidikan (LPP) UNS dan UPT Penerbitan dan Pencetakan UNS (UNS Press), Surakarta.

[39] Supriyadi, Kejahatan Terhadap Agama, Kedaulatan Rakyat, Yogyakarta, 20 Februari 2006.

[40] Trigg, Roger 2007, Religion in Public: Must Faith Be Privatized?, OXFORD University Prees, OXFORD.

[41] Umar, Nazarudin, Solusi Sufi Atas Aliran Sesat, diakses tanggal 2 Januari 2006 dari http://www.sufinews.com/index.php?wawancara.

[42] Van der Vyver, Johan D. dan Jr. John, Witte, 1996, Religious Human Rights in Global Perspective: Legal Perspectives, Martinus Nijhoff Publishers, London

[43] Wikipedia, Agama di Indonesia, diakses pada tanggal 22 April 2008 dari http://www.id.wikipedia.org/wiki/Agama_di_Indonesia.

[44] UN Declaration on The Elimination of All Forms of Intolerance and of Discrimination based on Religion or Belief (EAIDRB).

[45] UN Declaration on The Elimination of All Forms of Intolerance and Discrimination Based on Religion or Belief. Resolusi Majelis Umum PBB Tanggal 25 November 1981, dalam laporan Komite Ketiga (A/36/684/36/54)

[46] UN, Fact Sheet No.15, Third Edition.

[47] Undang-undang Nomor 39 Tahun 1999 tentang Hak Asasi Manusia

[48] Undang-undang Nomor 11 Tahun 2005 dalam Lembaran Negara Republik Indonesia Tahun 2005 Nomor 118, Tambahan Lembaran Negara Republik Indonesia Nomor 4557.

[49] Undang-undang Nomor 12 Tahun 2005 dalam Lembaran Negara Republik Indonesia Tahun 2005 Nomor 119, Tambahan Lembaran Negara Republik Indonesia Nomor 4558. 